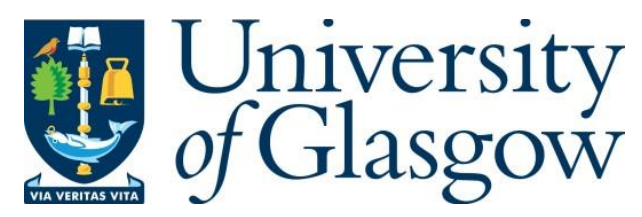

Eleftheriotis, D. (2017) Art, truth and reality, Cavafy and cultural studies: a personal perspective. Journal of Greek Media and Culture, 3(2), pp. 273-278.

There may be differences between this version and the published version. You are advised to consult the publisher's version if you wish to cite from it.

http://eprints.gla.ac.uk/151976/

Deposited on: 21 November 2017

Enlighten - Research publications by members of the University of Glasgow http://eprints.gla.ac.uk 


\section{Art, truth and reality, Cavafy, and cultural studies: a personal perspective}

We live in times when academics are urged to defend the truth and to act as experts and specialists. The calls come from all sides, more often than not from the right quarters, and are well justified. In the face of Trump's election, and a Brexit campaign that targeted the claims to truth made by experts, academic knowledge is seen as the last bastion of rationality, truth and reality. I have first-hand experience of that - here it goes: In my academic gown (sign of my power and status), I attend my students' graduation ceremony; after the degrees are awarded, I settle down to hear the Principal's message. The ceremony takes place a couple of weeks after Trump's shocking electoral success and the speech is powerful and moving: it is our academic duty to defend the truth, to instil reason and to change the world, we are told. I consider our Principal to be one of the most socially progressive of all UK vice chancellors/principals and his message resonates with the similarly progressive audience of our large civic university.

However, I become increasingly uncomfortable. The right to truth is not easy to claim in my discipline and our most productive studies of culture and media have historically revolved around the ways in which audiences engage with facts and fiction and not around how we distinguish between the two. The foundational text of cultural studies in the UK, Richard Hoggart's 1957 The Uses of Literacy, had at its heart not the truth about/in cultural forms but their 'uses' and their subsequent effects on society. Since the seventies cultural studies struggled to maintain the fine balance between the need to keep hold of the notion of an ultimate empirical truth with the more tangible task of analysing the cultural forms that claims to truth take, and identifying and deconstructing the effects of such claims. That is not work that turns its back to social responsibility: we have established through our interrogations of the past and the present that the worst kinds of oppression are justified in the name of ephemeral but powerful truths. That is why the Principal's call to defend truth is deeply awkward for me: unlike the 'hard sciences,' our truths are fleeting, intangible, transitory, difficult to define let alone defend, a perceived 'weakness' that makes it even harder for us to resist the hegemonic onslaught of STEMM (Science, Technology, Engineering, Mathematics, Medicine). I would however pose the following questions to our scientist colleagues: how many of your nineteenth and twentieth century truths are still true? How confident are you that your current truths will hold water in 50 years? In response to well-meaning counsels, I would be pointing out that universities do not simply exist to defend truth but also to question it. How are we going to change the world if we do not challenge its truths? And with such high political stakes to play for, how can we, cultural theorists and historians, resist the call to become experts? 
And another experience several months later: In Athens in late June, I exchange the harsh reality of the unbearable heat with the comfortable, air-conditioned, cultured reality of the National Museum of Contemporary Art that hosts part of Documenta 14. The move between realities is done in a split second as the doors smoothly let me into the wonderful, fresh, cool venue. Soon I realise that numerous other realities have taken hold of exactly the same space that my reality occupies: the art works index their own distant (chronologically and geographically) realities and all together make up a new complex reality, the exhibition; the other visitors seem to live in their own realities, too, created in their personal encounters with the deeply personal art works; and in my wandering in the building I discover cleaners working hard to make the reality of the visitors perfect.

But most of all I enjoy the views out of the museum, through the huge windows, the views of a reality that I have just escaped: Athens baking in the heat, the endless stream of taxis racing down Syggrou Avenue, the Parthenon in the horizon behind a cubist construction of air con units. Like parallel realities (nothing new in our world of complexity), the art works have a double function: they are documenta, paying testimony to their distant realities but they are also catalysts for the imagination, they recreate themselves endlessly in/through the eyes of the beholder. Like the glimpses of Athens out of the windows of the museum, they offer partial views of other experiences from other times and other places; and their stories are simultaneously witnessed and created by the visitors. Where is truth in all of this? And why 'truth' and 'reality' are so often used interchangeably even by some of the most insightful critics? It always puzzled me how Bazin fell for that.

Truth is an evaluation of the accuracy of the correspondence between reality and an account of reality - as demonstrated, for instance, in critical statements like 'a truthful representation of child poverty in Victorian London,' in which truth is inserted as a critical value in the evaluation of a work of art in relation to the historical reality it refers to. But strictly speaking, truth is not reality or even a part of reality - unless one is willing to expand the definition of reality to include accounts of it. The association of truthfulness with realism (and vice versa) has been one of the most hotly debated issues in cultural studies, peaking with the realism/modernism debates of the seventies and fine-tuned in the epistemological challenges of postmodernism in the eighties. Uncannily mirroring the parallel realities metaphor, the most productive work in cultural studies happened under the aegis of a paradigm that recognised and celebrated the polysemic nature of art and culture and proposed and explored a multiplicity of readings of works. While the precise nature of the relationship between art, truth and reality remains unresolved and ambiguous (which is not to say that it has not been theorised), the most exciting critical practices have always challenged our belief in notions of a fixed or true meaning of art works. The question 'what does this great artist truly intends?' has long been replaced by the question 'what readings are allowed, encouraged or enabled, by this great work of art?' Holding on, desperately at times in the face of post-structuralism and new historicism, to the possibility of a truth 
about the material conditions of the production of art works, cultural studies has dedicated its energy in challenges of notions of a fixed and definite truth in the work and in explorations of the multiplicities of experiences that any encounter with art initiates.

These are foundational principles for our discipline, not fixed but continuously reworked, and form the modus operandi of our critical practice and scholarship. It might feel a waste of time to go through old ground, after all it is the bread and butter of our discipline and we practice it daily. The only justification for this reiteration of the basics is that we are currently in a position that some of the fundamentals of our discipline are challenged in a variety of ways: the values of cultural studies within an academia squeezed by STEMM on the one side and 'creative economy' entrepreneurship on the other, become harder than ever to assert; intellectual speculation, exploration, commitment to proliferation of meaning and recognition of complexity are seen as unnecessary luxuries, socially disconnected, lacking in impact when faced with the menaces of Trump and Brexit and the chaos of globalisation going from bad to worse. Perhaps more importantly and definitely closer to home, the vicious attacks on his work on C.P. Cavafy (most comprehensively presented in his 2014 book Those People 'Made' Like Me: Queer Cavafy and the Poetics of Sexuality) of my co-editor, colleague and friend, Dimitris Papanikolaou, are also attacks on cultural studies and on the work that this journal champions and disseminates.

Disgusting as it is I will ignore the journalistic swarm of homophobic birds of prey that seems to feed on a sinister diet of bits and bobs of Papanikolaou's activities. I will note though, the personal cost that such attacks must have on him - I know I would be deeply upset if that was happening to me. I will also limit my discussion of the management of the Cavafy Archive to the simple statement that from what is publicly available and from a personal letter to me from the Onassis Foundation's Chair Antonis Papadimitriou, I am convinced that every effort is being made to make the Archive accessible and that the policy regarding openness is a particularly progressive one. What concerns me gravely and is exactly what lies behind the decision to engage with this 'controversy' is the regressive and oppressive critical framework deployed in these attacks, which goes beyond the personal and represents an assault on the foundational principles of cultural studies. Papanikolaou was recently the topic of a special issue (vol. 83, April 2017) of The Athens Review of Books. He was castigated by the 'expert' contributors for his queer reading of Cavafy and his role in the Archive. It is interesting to consider the alignment of two different but interconnected accusations that emerge from these critiques: an instrumental 'closing down' of the Archive, allegedly orchestrated by Papanikolaou, and a semantic 'closing down' that his rigorous pursuit of a queer reading imposes on Cavafy's poetry.

Freud would have a field day with such displacement and disavowal. Because it is the desperate need of the 'experts' to establish a static and fixed truth about and in the 
work of Cavafy, that imposes a de facto hermetic sealing of the Archive under a tombstone of limited (but 'true') accepted readings of Cavafy. For cultural theorists archives consist of documenta, which must aspire to include the forever surprising and innovative ways in which art works are reborn in their encounters with new audiences. The symbolic violence expressed in the deligitimisation of queer readings of Cavafy by the 'experts' is in fact what would render the Archive (and any archive) sterile and impoverished. That is a far more serious matter for cultural theorists and historians than the possible teething problems of the management of a recently (re)acquired archive.

But expertise always depends on hierarchical power for its potency, so where the expert might not magically posses it, authority is sought in 'uber-experts,' in this case in Daniel Mendelsohn. His conversation with Papanikolaou, which took place on the $12^{\text {th }}$ of January 2014 (https://www.youtube.com/watch?v=1F9PpFtiChw), is often cited by the 'experts' as the instance in which the 'uber-expert' 'forced Papanikolaou to shut his mouth' (' $\alpha \pi \sigma \sigma \tau о \mu \omega \sigma \varepsilon$ ') about the possibility of a 'queer Cavafy' critical practice. Readers can follow the link and check for themselves whether that is a truthful representation of the reality of a very friendly and dialogic conversation. That does not mean that in its course Papanikolaou and Mendelsohn agreed on everything. A fundamental difference emerged in their discussion that sums up what is at stake in this debate. Without rejecting the possibility that readers can make sense of Cavafy from an identity-informed position, Mendelsohn suggests that Cavafy's poetry must be read as a 'totality'. For Mendelsohn totality (the totality of meanings inherent in the works, that is) resides in Cavafy himself: "no writer writes with part of the brain on Tuesday and part of the brain on Wednesday[...] all writers write with every part of themselves all the time [...]' he explains. I do not know where the truth lies in that statement; an expert's (neuroscientist's? cognitive psychologist's?) view would be illuminating. That is, nevertheless, the truth that the 'experts' endorsed. Mendelsohn's take is unsurprising given his critical practice that follows in the footsteps of extremely lucid and insightful critics such as F. R. Leavis. I respect that approach and I have benefited from it myself, owing a significant part of my film studies training to V. F. Perkins.

As a cultural theorist and historian, however, Papanikolaou envisages a different totality, one that resides not in the artist's creativity and mind but in the reader's imagination, a totality that is always and necessarily partial, representing work that is constantly evolving, creating new possibilities with every new reading, contributing to an expansive, evolving, live archive. That is exactly where we have to draw the line, a clear methodological demarcation between an 'expert' critical approach to art and culture that desires fixed and final truths and a cultural studies approach that facilitates the recognition and creation of vibrant, dynamic, unpredictable and changing realities that pertain to works of art as living organisms. It is the indeterminacy and polysemy of art works that generates a truly open archive, and as it 
happens that also defines the mission of cultural studies. Our journal will continue to pursue such research resisting the multiple pressures that are currently applied.

One final thought in conclusion. Let us pay attention to Trump's depiction of everything that he dislikes as 'fake news' - fake, not false, not untrue, not unreal but fake. Now for someone who prides himself on his material possessions and his ability to own and gift expensive items, 'fake' is a loaded choice of word. 'Fake' designates objects that are cheap, inferior, objects for 'losers'. In that sense 'fake' introduces affect in the discourse, it incites anger: we are 'sold a fake'. The designation 'fake news' is not about challenging or reclaiming truth, it is about making his audience feel in a certain way. While Trump's lies must, and I am sure will be, confronted by appropriate institutions, in political terms it is Trump's affective mode of address that must be neutralised.

Cultural theorists and historians know that it is affect and emotions that we are best positioned to address, not claims to truth and reality. As opposed to many other disciplines cultural studies has not shied away from addressing pleasures, fears and desires and affect is prominent in its scope. What strikes me about the Cavafy 'controversy' in Greece is its affective aspect, the horrible personal attacks which are used as a powerful weapon in discrediting critical work. Papanikolaou as a proper cultural theorist and historian not only realises that our 'truths' potentially shape the reality of others but also uses and discusses affect in his liberating queer reading of Cavafy. He summons and cultivates in the readers of Cavafy the pleasures of recognition, the relief of sharing, the exhilaration in discovering others 'made' like you, the emancipating possibility of moving beyond the established truths of experts and oppressive societies. It is an exemplary approach that we are committed to defending and advancing further. 